\title{
EFFECT OF ABAMECTIN AND HEXAFLUMURON AGAINST COTTON LEAFWORM, SPODOPTERA LITTORALIS (BOISDVAL) UNDER LABORATORY AND FIELD CONDITIONS
}

\author{
S. A. Mahmoud \\ Plant Protection Research Institute, ARC., Giza Egypt. \\ E mail:Sobhy90@yahoo.com
}

Received: Dec. 17, 2016

Accepted: Jan. 1, 2017

\begin{abstract}
Field and laboratory experiments were conducted in Fayoum. Governorate during 2013 and 2014 cotton seasons to evaluate the effect of abamectin against cotton leafworm, Spodoptera littoralis. The obtained results indicated that 5 days after treatment the larval mortality percentages were 93.77 , $89.95 \%$, comparing with 98.95 and $95.85 \%$ for the recommended IGR hexaflumuron (consult) at 2013 and 2014, respectively, while it was, 10 days after application of abamectin 88.4 and $78.22 \%$ reductions comparing with 96.91 and $94.72 \%$ for the hexaflumuron, at 2013 and 2014 cotton seasons, respectively. As the residual effect, after 15 days it was 72.3 and $68.11 \%$ for abamectin and $94.17,92.45 \%$ for hexaflumuron, at 2013 and 2014 , respectively. The overall reduction was $84.8,78.8 \%$ for abamectin and 96.4, 94.3\% for hexaflumuron at 2013 and 2014 , respectively. Laboratory trials revealed that $L C_{50}$ and $L C_{90}$ of abamectin on cotton leafworm were 2.78 and $48.56 \mathrm{ppm}$ at $L C_{50}$ and $L C_{90}$, respectively, while it was 6464.2 and $100487.0 \mathrm{ppm}$ for hexaflumuron. The slope values were $1.03 \pm 0.16$ and $1.08 \pm 0.23$ for abamectin and hexaflumuron, respectively.
\end{abstract}

Key words: IGR, hexaflumuron, abamectin, biopesticide, control, slope , lethal dose.

\section{INTRODUCTION}

Spodoptera littoralis in the major pest destructive cotton fields in Egypt. The insecticides represented the major element for controlling these pests for many years ( Verkery and Wright, 1996, Pinadoz et al., 2004, and MacBean ,2012). The environment, animals and human strongly affected by these hazard insecticides as well as the insects become resistance in the different degrees to their actions. So, it is necessary to use safe control agents including chemicals of new mode of action in control programs of both insect pests. Among the bioinsecticides, abamectin was found to be the last with the highest selective toxicity than insecticides.

This work aimed to evaluate the effect of abamectin and the IGR, hexaflumuron against Spodoptera littoralis under field and laboratory conditions.

\section{MATERIALS AND METHODS}

Field and laboratory trials were carried out to evaluate the effect of abamectin and the IGR, hexaflumuron against the cotton leafworm, Spodoptera littoralis, the major cotton insect pest in Egypt.

\section{Field trials:}

Field experiments were carried out in Fayoum Governorate during 2013 and 2014 cotton seasons.

\section{Cotton leafworm trials:}

The abamectin $(250 \mathrm{ml})$ was evaluated against Spodoptera littoralis in cotton field. Egg masses in three feddans of cotton field were most collected and left to hatching. When the hatched larvae reached to about the end of $3^{\text {rd }}$ instar larvae, the area was divided into two equal areas of one feddan for each, representing the three treatments, abamectin, hexaflumuron and control. The number of active larvae per 100 cotton plants were counted for every treatment before pesticide applications, except the newly hatched larvae in the egg masses, then 400 liters of each pesticide was performed using $400 \mathrm{~L}$ spraying motor. The 
number of larvae per 100 cotton plants were counted 5,10 and 15 days after spray.

The reduction in numbers of larvae after 5 days was represented initial kill and the average reduction after 10 and 15 days was represented residual effect.

\section{laboratory trials:}

A susceptible strain of Spodoptera littoralis was used in experiment. Using dipping technique disks of castor bean leaves were dipped in gradual concentrations solutions of abamectin for 10 second and left to dryness and then offered to the $2^{\text {nd }}$ the larval instar in glass containers. Every glass containers contains 100 larvae and three replicates were used for every concentrations and the control using castor bean leaves dipped water only and dried castor bean leaves before offered to the larvae. After treatment the larvae were held in at room temperature after $24 \mathrm{hrs}$, the experiment was investigated and the dead larvae were recorded and removed. The a live larvae were transferred to another glass container contain untreated castor bean leaves. The experiment was investigated daily till $5^{\text {th }}$ day. The percent mortalities of larvae after 5days were calculated and corrected when needed using Abbott ${ }^{s}$ formula (1925), $L_{50}$ and $L C_{90}$ were calculated to Finney (1971).

Henderson and Tilton (1955) equation was used to evaluate the reduction percentages of cotton larvae:

Reduction \% =

$$
\left[1-\left(\frac{\text { Treatment after }}{\text { Treatment before }} \times \frac{\text { Control before }}{\text { Control after }}\right)\right] \times 100
$$

\section{RESULTS AND DISCUSSION Field trials \\ The effect of abamectin and hexaflumuron against cotton leafworm, Spodoptera littoralis:}

The effect of abamectin against the cotton leafworm, Spodoptera littoralis during
2013 and 2014 cotton seasons evaluated and the obtained data presented in. For the initial kill which represented the percent reduction in the Table (1) numbers of the cotton leafworm larvae after 5 days of abamectin resulted in 93.77, $89.95 \%$, reductions in 2013 and 2014 cotton seasons, respectively, comparing with 98.95 and $95.85 \%$ for the recommended IGR hexaflumuron.

According to the residual effect, as shown in Table (1), 10 days after application of abamectin the reduction percentages in leafworm larvae were 88.4 and $78.22 \%$ comparing with 96.91 and $94.72 \%$ for the hexaflumuron, at 2013 and 2014 cotton seasons, respectively. Furthermore, as a residual effect, after 15 days reduction percentages in leafworm larvae were 72.3 and $68.11 \%$ for abamectin and 94.17 , $92.45 \%$ for hexaflumuron, at 2013 and 2014 , respectively.

The overall mean reduction of cotton leaf worms were $84.8,78.8 \%$ for abamectin and $96.4,94.3 \%$ for hexaflumuron at 2013 and 2014 , respectively. .

Cock et al., (2007) found that the Emamectin benzoate controlled $S$. exigua infestation in cotton plant up to 10 days after treatment compared to control. Prasad et al., (2007) reported that Emamectin was most toxic against $S$. litura followed by Novoluron indoxacarb .

The previous data appeared highly effect of abamectin in controlling the larvae of cotton leafworm and strongly showed a promise in using this agent as bio insecticide in integrated control management of cotton leafworm, especially because it has a new mode of action than that of the recommended insecticides for this pest and it also for its low toxicity against beneficial insect. 
Table (1): The effect of abamectin comparing with the recommonded insect growth regulater (IGR) hexaflumurion against the cotton leafworm, S.littoralis during 2013 and 2014 cotton seasons.

\begin{tabular}{|c|c|c|c|c|c|c|}
\hline \multirow[t]{2}{*}{$\begin{array}{l}\text { Insecticides } \\
\text { Dose/feddan }\end{array}$} & \multirow[t]{2}{*}{$\begin{array}{l}\text { No. of } \\
\text { the } \\
\text { larvae }\end{array}$} & \multicolumn{3}{|c|}{$\begin{array}{c}\text { Number of collected larvae } \\
\text { ( reduction percentages) }\end{array}$} & \multirow{2}{*}{$\begin{array}{c}\text { Overall } \\
\text { mortality } \\
\%\end{array}$} & \multirow[t]{2}{*}{$\begin{array}{c}\text { Hatchability } \\
\%\end{array}$} \\
\hline & & 5 days & 10 days & 15 days & & \\
\hline \multicolumn{7}{|c|}{2013} \\
\hline \multirow{2}{*}{$\begin{array}{l}\text { Abamectin } \\
250 \mathrm{ml}\end{array}$} & \multirow{2}{*}{650} & 46 & 61 & 18 & \multirow{2}{*}{84.8} & \multirow{2}{*}{80.8} \\
\hline & & (93.77) & (88.4) & (72.3) & & \\
\hline \multirow{2}{*}{$\begin{array}{c}\text { Hexaflumurion } \\
250 \mathrm{ml}\end{array}$} & \multirow{2}{*}{1200} & 25 & 30 & 7 & \multirow{2}{*}{96.4} & \multirow{2}{*}{93.1} \\
\hline & & (98.17 & (96.91) & $(94.17)$ & & \\
\hline control & 1100 & 1250 & 890 & 110 & - & 98 \\
\hline \multicolumn{7}{|c|}{$\begin{array}{l}2014 \\
\text { season }\end{array}$} \\
\hline \multirow{2}{*}{$\begin{array}{l}\text { Abamectin } \\
250 \mathrm{ml}\end{array}$} & \multirow{2}{*}{880} & 100 & 85 & 61 & \multirow{2}{*}{78.8} & \multirow{2}{*}{79.19} \\
\hline & & (89.95) & (78.22) & $(68.11)$ & & \\
\hline \multirow{2}{*}{$\begin{array}{l}\text { Hexaflumurion } \\
250 \mathrm{ml}\end{array}$} & \multirow{2}{*}{1280} & 60 & 30 & 21 & \multirow{2}{*}{94.3} & \multirow{2}{*}{90.25} \\
\hline & & $(95.85)$ & (94.72) & $(92.45)$ & & \\
\hline control & 1150 & 1300 & 510 & 250 & - & 98 \\
\hline
\end{tabular}

\section{Laboratory trials:}

Data recorded in Tables $(2 \& 3)$ revealed that $\mathrm{LC}_{50}$ and $\mathrm{LC}_{90}$ of abamectin on the fourth instar larvae of cotton leafworm were 2.78 and $48.56 \mathrm{ppm}$, respectively, while it was 6464.2 and $100487.0 \mathrm{ppm}$ for hexaflumuron .

The slope values were $1.03 \pm 0.16$ and $1.08 \pm 0.23$ for abamectin and hexaflumuron, respectively.

These results are harmony with those of Argentinet, et al., (2002) and Biroh et al.,
(2008), in addition Dhawan et al., (2007) who found that the $\mathrm{LC}_{50}$ values of Emamectin benzoate against the third larvae of Spodoptera littoralis was $0.0001 \mathrm{ppm}$ and Emamectin benzoate was the most toxic insecticide comparing to other treated insecticides.

The obtained results showed a promising results to use abamectin in the integrated control programs of lepidopterous insects especially cotton leafworm, $S$. littoralis. 
Table (2): The $\mathrm{LD}_{50}, \mathrm{LD}_{90}$ and slope of the abamectin on $4^{\text {th }}$ stage larvae of cotton leafworm, S.littoralis

\begin{tabular}{|c|c|c|c|c|c|c|}
\hline \multirow{2}{*}{ Days } & \multicolumn{6}{|c|}{ Abamectin } \\
\cline { 2 - 7 } & LC $_{50}$ & Slope & Confidence limits & LC $_{90}$ & Slope & Confidence limits \\
\hline $\mathbf{2 4} \mathbf{~ h r}$ & 2.78 & $1.03 \pm 0.16$ & $1.304-4.82$ & 48.56 & $1.03 \pm 0.16$ & $25.57-132.53$ \\
\hline $\mathbf{4 8} \mathbf{~ h r}$ & 2.12 & $1.097 \pm 0.21$ & - & 31.10 & $1.097 \pm 0.21$ & - \\
\hline $\mathbf{7 2} \mathbf{~ h r}$ & 0.37 & $0.83 \pm 0.22$ & - & 12.68 & $0.83 \pm 0.22$ & - \\
\hline
\end{tabular}

Table (3): The $L D_{50}, L D_{90}$ and slope of the hexaflumuron on $4^{\text {th }}$ stage larvae of cotton leafworm, S.littoralis

\begin{tabular}{|c|c|c|c|c|c|c|}
\hline \multirow{2}{*}{ Days } & \multicolumn{5}{|c|}{ Hexaflumuron } \\
\cline { 2 - 7 } & LC $_{50}$ & Slope & $\begin{array}{c}\text { Confidence } \\
\text { limits }\end{array}$ & LC $_{90}$ & Slope & Confidence limits \\
\hline $\mathbf{2 4} \mathbf{~ h r}$ & 6464.2 & $1.08 \pm 0.23$ & $3859.4-16057.4$ & 100487.0 & $1.08 \pm 0.23$ & $31470.1-1592859.7$ \\
\hline $\mathbf{4 8} \mathbf{~ h r}$ & 670.01 & $1.17 \pm 0.19$ & $362.24-1061.1$ & 8421.95 & $1.17 \pm 0.19$ & $4631.82-22982.91$ \\
\hline $\mathbf{7 2} \mathbf{~ h r}$ & 156.90 & $1.10 \pm 0.19$ & $54.21-296.09$ & 2293.44 & $1.10 \pm 0.19$ & $1319.93-5161.22$ \\
\hline
\end{tabular}

\section{REFERENCES}

Abbott, W. S. (1925). A method for computing the effectiveness of an insecticide. J. Econ. Entomol ., 18: 265 267.

Argentinet, A., R. k. Jansson, W. R. Halliday, D.Rugg and C. S. Jang (2002). Potency spectrum and residual activity of four new insecticides, under glass house conditions. Florida. Entomologist, 25: 552 -262 .

Biroh, A., M. Raghuraman, S. Brijesh and G. P. Gupta (2008). Impact of abamectin complex in cotton. Indian Journal of Entomology, 70: 259 - 263.

Cock, D. K. ; B. K. leonard and C. T. Gore (2007): Field and laboratory performance of noval insecticides against armyworm(Lepidoptera: Noctuidae). Florida. Entomologist, 87: 433 - 439.

Dhawan, A. J. S. Saiw, B. Mohindru and K. Singh (2007). Susceptibility of Spodoptera litura (Fabriciug) to some noval insecticide. Pesticide Research Journal, $19: 159-171$.

Finney, D. J. (1971): Probit analysis. 3 rd, Cambridge University. Press, New York. $333 \mathrm{pp}$
Henderson, C. P. and E. W. Tilton (1955). Tests with acaricides against the brown white mite. J. Econ. Entomol. 98: 157161.

MacBean, C. (2012). A World Compendium The Pesticide Manual Sixteenth Edition Supplementary Entries - Extended Editor: C. MacBean. (C) 2012 BCPC (British Crop Production Council)

Prasad, K. D., T. Madhumathi, P.A. Roa and V. S. R. Roa (2001). Toxicity of insecticide to resistant strain of Spodoptera litura (Fab.) on cotton. Annals of Plant Protection Science, 15: 27- 82.

Pinadoz, S., F. Budo, M.I. Schineider, A. Gobbi, E. Unuela, J. Ualla and P. D. Estal (2004). Effect of two botanical insecticides, Spinusad and Methosyfenozide on Spodoptera littoralis (Boisd) (Lepidoptera: Noctuidae). under laboratory condition. J. Econ. Entomol. 97: 1906-1911.

Verkery, R. H. J. and D. J. Wright (1996). Effect of interaction between host plants and selective insecticides on larval of Plutella xylostella in laboratory. Pesti.Sci., 46: 171- 181. 
تأثثير فعالية الأبامكتن والهكسا فلومورون معليا وحقليا على دودة ورق القطن

\section{صبحى عبد الظاهر محمود إسماعيل}

معهد بحوث وقاية النباتات- مركز البحوث الزراعية- الجيزة - مصر

الملخص العربي

إجريت التجارب المعملية والحقلية بمحافظة الفيوم مركز أبشواي معمليا وحقليا خلال عامى (2013- 2014) لتقييم تأثير فعالية الأبامكتن ومنظم النمو الهكسافلومورون على دودة ورق القطن.

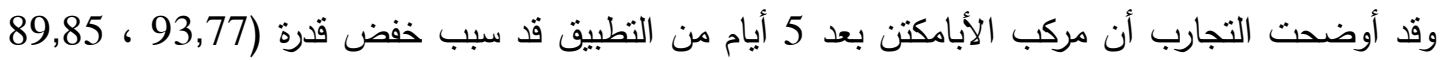
\%) فى تعداد يرقات ورق القطن مقارنة بنسب خفض فى تعداد يرقات ورق القطن قدرة (98,17 ، 95,85 ٪ ) ) لمركب الهكسافلومورون خلال موسمى القطن 2013 ، 2014 على التوالى. بينما الأثر المتبقى لمركب الأبامكتن بعد 10 ، 15 يوم من التطبيق أظهر خفض فى تعداد يرقات دودة ورق القطن قدرة (88,4 ، 78,2 \% ٪ )

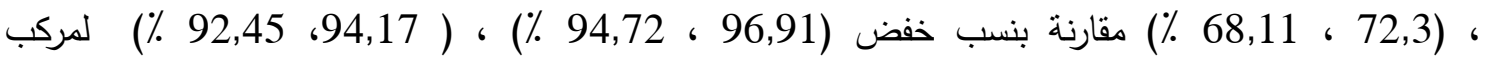
الهكسافليمورون موسمى القطن 2013 ، 2014 على التوالى. كان متوسط نسب الموت الكلية لليرقات 84.8 ، 848 ،

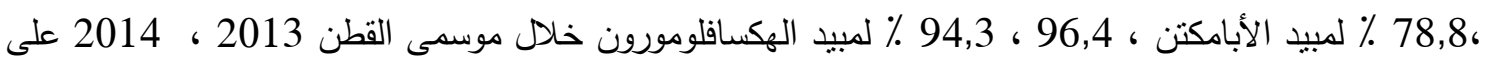

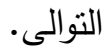

في حين أوضحت التجارب المعلية أن قيمة LC الأبامكتن كانت 28,56 ، 2,78 وقيمة الانحدار 1,03 ـ 0,16 وكانت القيم

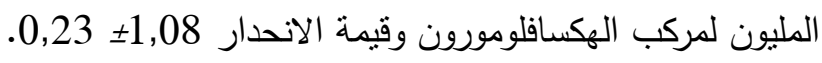

